\title{
多段階水媒体不均一重合によるポリメタクリル酸メチルー ポリスチレン複合ポリマーの生成
}

\author{
山崎 信助*1 $・$ 服部 滋*1 ・ 浜島 求女*1
}

(受付 1976 年 3 月 3 日・蕃查終了 1976 年 7 月 8 日)

\begin{abstract}
要 旨 1 個の粒子中に 2 成分以上のポリマーを含む多層構造の複合ポリマーラテックスの生成方 法と生成条件を検討するため, ポリメタクリル酸メチルとポリスチレンから成る 2 層構造の複合ポリ マーラテックスの重合条件と生成ポリマーラテックスの重合条件と粒子状態の関係を検討した。 また 得られた複合ポリマーラテックスを乾燥した微粉末ポリマーは，ガラス相ポリマーどうしの相溶性の 悪い 2 成分系ポリマーの不均一混合物であるが，圧縮成形したポリマーは予想以上の強度が保持きれ ることが認められた。 また成形ポリマーの透明性は, 複合ポリマーラテックスの粒子径の大きさに 依存して, 粒子径が $3000 \mathrm{~A}$ 以上の場合は真珠様の干涉色をもった乳白色の不透明なポリマーであ り, 粒子经が $2000 \mathrm{~A}$ 以下の場合は, 見る角度によって色の変わってみえる透明なポリマーが得られ た.
\end{abstract}

\section{1 緒言}

1 個のポリマー粒子中に, 2 成分以上のポリマーを層 状に含むところの多層構造の複合ポリマーラテックスを 得る方法は, ラテックス工業の面からも興味ある問題で あるが，報告例は少ない，

またこのポリマー粒子中に 2 成分以上のポリマーを 層状に含むポリマーラテックスはポリマーのミクロ的な 不均一混合物であるので従来技術のブレンド方法では困 難とされていた非相溶性で, ガラス転移温度の高いポリ マーどらしのブレンド物などの新しい領域のブレンドポ リマーを得る方法としても興味ある問題である.

本報では，1 個のポリマー粒子中に 2 成分以上のポリ マーを含む多層構造の複合ポリマーラテックスの生成方 法と生成条件について検討するため, メタクリル酸メチ ルとスチレンから成る系を選び, 重合条件と電子顕微鏡 による生成ポリマーラテックスの粒子状態の関係につい て検討した。 また，生成した複合ポリマーラテックスを 䫧燥して得た微粒子は, 従来あまり検討のなされなかっ たガラス相のみから成る 2 成分ポリマーのミク口的な不 均一混合物であるので，压縮成形によって得られる成形 樹脂の二三の性質についても定性的な検討を加えた，そ の結果, 混和性の乏しいとされているポリメタクリル酸 メチルとポリスチレンのような二つのガラス相のみから 成る複合物む1), ミク口的不均一混合が行われると, 強 度的にも成分ボリマー単独の場合と, ほとんど変わらな

*1 東京工業試酸所 ( 151 東京都沾谷区本町 1-1) いiridescent color（見る角度によって变わる色）の特 異な樹脂が得られたので報告する。

\section{2 実験}

\section{1 実験に用いた試菜}

メタクリル酸メチル拈よびスチレンモノマーは, 市販 品をシリカゲルで脱水の後, 窒素気流中, 減圧下で蒸留 を行って，その中間留分を $-15^{\circ} \mathrm{C}$ 以下に保存して使用 した. 重合開始剤の過硫酸カリウムとチオ硫酸ナトリウ ムおよび硫酸銅は，市販品（特級）をそのまま使用し た. 媒体の水は, 蒸留水を重合フラスコ中で, 高純度窒 素を通入しながら $30 \mathrm{~min}$ 以上加熱してから用いた。重 合停止剂としては， $\alpha$-ニトロソフェニルヒドロキシルア ミンのアンモニウム塩の $0.1 \%$ 水溶液を用いた22.

\section{2 実験方法}

\subsection{1 重合方法と重合条件}

窒素ガス導入管, 温度調節用サーミスタ, 還流冷 却 器, $\mathrm{pH}$ 調節用複合ガラス電極, 拉よびかきまぜ装直 (回転軸がスリ合せ方式で，かきませ棒に弦長 $9 \mathrm{~cm}$ の 半月形のかくはん片を付したもの）を付した $2000 \mathrm{ml} の$ 四つロセパラブルフラスコ中, 水 $1600 \mathrm{ml}$ に所定量のモ ハマー(メタクリル酸メチル, スチレン) を分散させ, 高純度窒素を一定速度 $(150 \mathrm{~m} / / \mathrm{min})$ で吹き込みなが ら, 重合采内の温度を $70 \pm 0.5^{\circ} \mathrm{C}$ に保って重合を行っ た.

重合は2 段階に分けて行い, 第 1 段階目の重合として メタクリル酸メチルを, 等モル濃度の過硫酸カリウムと 
チオ硫酸ナトリウムから成るレドックス系重合開始剂を 用いて，所定量濃度の硫酸銅水溶液を添加して重合が完 全に終了するまで行う.ついで所定量のスチレンモノマ 一を添加して，過硫酸カリウムを重合開始剤として第 2 段階目の重合を行った，かきまぜ速度は $250 \pm 10 \mathrm{rpm}$ に保ち, 重合系内の $\mathrm{pH}$ 值は, 常に $\mathrm{pH} 2.5 \sim 3.5$ の 一定範囲に保った. 重合率は生成ポリマーラテックスを 赤外線ランプで蒸発乾燥して重量を測って求めた。また 重合の完了時間は, 重合系が発泡してきて残存モノマー 臭がほとんどなくなった時間とした。

\subsection{2 粒子状態の測定}

重合采から採取した試料は，重合禁止剂を含む水で希 釈し，そつ試料の 1 滴をシートメッシュ上にとり，電子 顕微鏡で直接倍率 10500 倍で撮影を行った. 得られた 写真フィルム上のポリマー微粒子像は, 倍率 25 倍のコ ソパレーターを用い，1試料につき 100 ５00 個の粒子 像の粒子径を測定した。この粒子像の直径は 1152 本/ $\mathrm{mm}$ の回折格子の白金一パラジゥムレプリカ膜の線幅 を用いて倍率の補正を行い統計的に粒子径の平均値と標 準㣂差值を求めた. 水媒体中の粒子数は, 粒子の比重を 1.20 と仮定して粒子の平均径と重合収量から算出して 求めた。

\subsection{3 王縮成形による混融フレントポリマーの生成}

複合ポリマーラテックスを十分乾燥させて得たポリマ 一微粉末を, $140^{\circ} \mathrm{C}$ に予熱した成形用金型に一定量と り, 温度 $140 \sim 160^{\circ} \mathrm{C}$, 压力 $60 \mathrm{~kg} / \mathrm{cm}^{2}$ て 3 分間圧縮成 形を行った，成形樹脂片の厚さは， $3 \mathrm{~mm}$ と $0.5 \mathrm{~mm}$ の 2 種類作成し，外観などを定性的に比較検討した.

\subsubsection{GPC による複合ポリマーの分子量分別}

Waters 社 ANA-PREP 型 GPC の分取用部分 (力 ラム数 3 本) を用い，ベンゼンを溶媒として， $40^{\circ} \mathrm{C}$ 流 速 $30 \mathrm{ml} / \mathrm{min}$, 試料濃度 $0.5 \mathrm{~g} / 100 \mathrm{ml}, 1$ フラクション $300 \mathrm{ml}$ の条件で分取を行い分別曲線を求めた.

\section{3 実験結果と考察}

\subsection{2 層構造複合ポリマーラテックスの生成}

微細なポリーー粒子中に化学組成と組成比の異なる 2 成分以上のポリーーが層状に分布している Core-shell 構造の複台ポリマーラテックスを得る方法について検討 した.

層状構造の複合ポリマーラテックスを得る方法として これまで報告されてきた例は，中心層を構成するモノマ 一を先に乳化重合させ, 完全に重合が完了した後, 外殻 層を構成するモノマーを添加して，先に重合したポリマ 一粒子を核種粒子として, 粒子上で乳化重合を完結させ るシード乳化重台の方法がとられている、方）この場合 ポリーーラテックスの分散安定性を保持させるため, 乳 化刜を添加して重合を行ら必要があるが, 乳化剂の添加
量が多いと新しい粒子の生成が起こり, 粒子径分布が広 がってきて，生成ポリマーラテックスは組成の異なった 2 種類の粒子を生成するようになり，また乳化剂が少な すぎるとポリマーラテックスは凝集するため乳化剤量の 調節が非常に難しい.

最近，松本，大久保ら ${ }^{\theta)}$ は BPO などの油溶珄の開始 剂を含有させたアクリル酸エチルを水溶性のレドックス 開始剂で乳化重合を行って核種ポリマーを生成し，つ で $60^{\circ} \mathrm{C}$ 以上の温度でスチレンの乳化重合を行って比較 的多量の乳化剂の存在下でもシード重合が行えることを 示し,アクリル酸エチルとスチレンなどの 2 層構造の複 合ポリマーの生成と粒子構造について報告している.

著者らは，重合条件によっては比較的親水性のモノマ 一であるメタクリル酸メチルやアクリル酸エチルが，水 媒体中ソープフリ一の状態でも粒度分布の均一な分散安 定性の良いポリマーラテックスを生成することと7), メ タクリル酸メチルの水媒体不均一重合反応に拈けるポリ マ一粒子の平均粒子径とポリマー粒子内のモノマ一吸着 量の関倸 ${ }^{8)}$ および粒子径と粒度分布に関する前報 ${ }^{8)}$ の知 見をもとにして, 水媒体中ソープフリー状態で段階的に 成分モノマーの不均一重合を行って 2 成分以上のポリマ 一を含有する複合ポリマーラテックスを生成する方法の 検討を行った.

水媒体中で段階的に成分モノマーの不均一重合を行う ためには，第 1 段階目の重合で生成するポリマーラテッ クスは粒度分布が均一であることと，分散安定性が良い ことが必要であるが，さらにその粒子径と粒子数が重要 な因子である. メタクリル酸メチルの水媒体不均一重合 にさいして生成ポリマー粒子の平均粒子径と, 粒子内の モノマー吸着量の関係は, 前報8) で明らかにしたよらに 粒子径が $1000 \mathrm{~A}$ 以下の場合は粒子中のモ, マ濃度は 一定の状態で重合が進み,この場合は, ポリマー粒子は 遊離のモノマー油滴に対して, 親和性が小さく, モノマ 一油滴中には全くポリマー粒子は溶解抽出されることは ないが，生成ポリマーの粒子径が $2000 \mathrm{~A}$ 以上になると ポリマー粒子に対するモノマーの吸着量が著しく増大し て,この場合はポリマー粒子は多量のモノマーを吸収し て全体が膨潤した状態になり, 相互に合一したり, 遊維 のモ/マー油滴中にポリマー粒子が溶解抽出され, 多量 の塊状物を生成することが知られている8 .

また, さらに生成ポリマーラテックスの粒子径が $3000 \sim 4000 \mathrm{~A}$ 以上に成長すると, 重合系内に遊離の ノマーが存在する場合は, 重合の経過とともに, 別に新 しい重合の活性核種を生成して重合が進むようになり, 粒子相互の合一とともに粒度分布が著しく広がってくる ので日)，第 1 段階目に生成するポリマーラテックスの粒 子数はできるだけ多くして, 粒子径を小さくすることが 必要である. 
多段階水媒体不均一重合によるポリメタクリル酸メチルーポリスチレン複合ポリマーの生成

Table 1. The effects of initiator and promoter concentration on the particle size of the polymer composite latex.

\begin{tabular}{|c|c|c|c|c|c|c|}
\hline \multicolumn{2}{|c|}{ Concn. of initiator } & \multirow{2}{*}{$\begin{array}{c}\text { Concn. of } \\
\text { promoter } \\
\mathrm{CuSO}_{4} \\
\left(\times 10^{8} \mathrm{~mol} / l\right)\end{array}$} & \multicolumn{2}{|c|}{ Amount of monomers } & \multicolumn{2}{|c|}{$\begin{array}{c}\text { Completion time of } \\
\text { polymerization }\end{array}$} \\
\hline \multicolumn{2}{|c|}{$\mathrm{K}_{2} \mathrm{~S}_{2} \mathrm{O}_{8} \underset{\left(\times 10^{3} \mathrm{~mol} / l\right)}{\mathrm{Na}_{2} \mathrm{~S}_{2} \mathrm{O}_{3}}$} & & $\underset{(\mathrm{m} l)}{\operatorname{MMA}}$ & $\begin{array}{l}\mathrm{ST} \\
(\mathrm{m} l)\end{array}$ & $\underset{(\min )}{\text { MMA }}$ & $\underset{(\mathrm{min})}{\mathrm{ST}}$ \\
\hline 1.0 & 1.0 & 2.5 & 100 & 100 & - & 60 \\
\hline 5.0 & 5.0 & 25.0 & 100 & 100 & 13 & 75 \\
\hline 5.0 & 5.0 & 2.5 & 100 & 100 & 20 & 35 \\
\hline 5.0 & 5.0 & 0.25 & 100 & 100 & 15 & 25 \\
\hline 5.0 & 5.0 & nil & 100 & 100 & 30 & 90 \\
\hline 10.0 & 10.0 & 2.5 & 100 & 100 & 10 & 25 \\
\hline 10.0 & 10.0 & 0.25 & 100 & 100 & 10 & 15 \\
\hline \multicolumn{3}{|c|}{ Particle diameter } & \multicolumn{4}{|c|}{ Total number of particles } \\
\hline \multicolumn{2}{|c|}{ Core $\underset{(\mathrm{A})}{\text { particle }}$} & $\begin{array}{c}\text { Composite particle } \\
\text { (A) }\end{array}$ & \multicolumn{2}{|r|}{$\begin{array}{l}\text { Core particle } \\
\left(\times 10^{-16}\right)\end{array}$} & \multicolumn{2}{|c|}{$\begin{array}{l}\text { Composite particle } \\
\left(\times 10^{-16}\right)\end{array}$} \\
\hline \multicolumn{2}{|c|}{$1053 \pm 45$} & $1501 \pm 97$ & \multicolumn{2}{|r|}{12.2} & \multicolumn{2}{|c|}{8.42} \\
\hline \multicolumn{2}{|c|}{$1073 \pm 40$} & $1466 \pm 53$ & \multicolumn{2}{|r|}{11.5} & \multicolumn{2}{|c|}{9.0} \\
\hline \multicolumn{2}{|c|}{$1802 \pm 61$} & $2126 \pm 73$ & \multicolumn{2}{|r|}{2.43} & \multicolumn{2}{|c|}{2.9} \\
\hline \multicolumn{2}{|c|}{$2187 \pm 40$} & $3136 \pm 51$ & \multicolumn{2}{|r|}{1.36} & \multicolumn{2}{|c|}{0.9} \\
\hline \multicolumn{2}{|c|}{$2725 \pm 503$} & $10724 \pm 956$ & \multicolumn{2}{|r|}{0.7} & \multicolumn{2}{|c|}{-} \\
\hline \multicolumn{2}{|c|}{$2021 \pm 96$} & $2950 \pm 71$ & \multicolumn{2}{|r|}{1.7} & \multicolumn{2}{|c|}{1.1} \\
\hline \multicolumn{2}{|c|}{$2225 \pm 80$} & $3174 \pm 98$ & \multicolumn{2}{|r|}{1.3} & \multicolumn{2}{|c|}{0.9} \\
\hline
\end{tabular}

Polymerization conditions: dispersion medium, water $1600 \mathrm{ml}$; atmosphere, nitrogen; temperature, $70 \pm 0.5^{\circ} \mathrm{C} ; \mathrm{pH}, 2.5 \sim 3.5$; rate of stirring, $250 \pm 10 \mathrm{rpm}$. (lune type paddle, $9 \mathrm{~cm}$ )

生成複合ポリマーの層構造の確認法としては, シード 乳化重合の場合は生成複合ポリマーラテックスの最低造 膜温度之組成比の関(系 ${ }^{(2), 10)}$ 皮膜の動的粘弾性 ${ }^{11)}$ や機械的

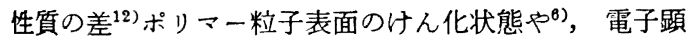
微鏡による三重構造粒子の超薄片像 ${ }^{4}$, 粒子の内部構造

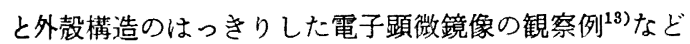
によって層構造が知られているが，水媒体不均一重合の 場合でも同様の方法で層構造が示される ${ }^{14)}$.

またポリメタクリル酸メチルとポリスチレンのような ガラス温度の高いポリマーどうしの場合は上述の方法は 困難であるが，第 1 段階目の重合で生成したポリメタク リル酸メチルの粒子径が $700 \sim 1500 \mathrm{~A}$ ぐらいの場合はモ ノマー油滴に対して親和性が小さく, 添加されたスチレ ンモノマーにはポリマーラテックスは溶解抽出されない し，スチレンモノマーは, ポリマーラテックス粒子上の モノマ一の吸収を阻害している水和層を通して一定濃度 の状態でモノマーが吸着していると考えられる8).この ような場合は, 粒子の表面層ないし表面層に近いところ で重合が起こっており, 粒子全体がモノマーで膨潤して いないので，そのまま 2 層構造の複合ポリマーラテック スが形成すると考えられる.この水和層を通して一定濃
度のモノ、ーが粒子表面に吸着して表面層ないし表面層 に近いところで重合が進むとの見解は層構造のポリマー ラテックス生成の重要な根拠となる考えである.

初期の乳化重合の理論的扱いでは, ポリマーはモノマ 一に溶解する場合は, 粒子中のモノマーはポリマー粒子 の中心から表面に対して濃度こう配はなく，モノマーは 均一に膨潤していると仮定し, 粒子径とモノマ一量の関 係を Gardon ${ }^{15)}$, Vanzo ${ }^{18)}$, Flory ${ }^{17)}$ らは膨潤と界面張 力の平衡から説明している. しかし, 粒子中にモノマー が均一に存在するとした Gardon ${ }^{15)}$ らの仮定は, 現実 に層構造の複合ポリマーが生成しているといら事実だけ

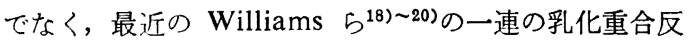
応における “Core-Shell 形態” の研究からも疑問視さ れ，粒子径が小さい場合は，重合反応はポリマー rich の中心層をとりまいているモノマー rich の shell 凮で あるモノマーで膨潤している表面層あるいは表面層に近 いところで進むとする見解が支持されている21).

さらにStabenow ら ${ }^{13)}$ が ABS 樹脂の構造の研究でゴ ムラテックスにスチレンーアクリロニトリルを添加して 重合するとゴムラテックスの粒子径が 750A と小さい場 合はCore一Shell 型の粒子となるが，ゴム粒子が 3400A 
Table 2. The effect of temperature on the formation of the polymer particle.

\begin{tabular}{|c|c|c|c|c|c|c|c|c|}
\hline \multirow{2}{*}{$\begin{array}{c}\text { Temper- } \\
\text { ature } \\
\left({ }^{\circ} \mathrm{C}\right)\end{array}$} & \multicolumn{2}{|c|}{$\begin{array}{l}\text { Amount of } \\
\text { monomers }\end{array}$} & \multicolumn{2}{|c|}{$\begin{array}{c}\text { Time of } \\
\text { polymerization }\end{array}$} & \multicolumn{2}{|c|}{ Particle diameter } & \multicolumn{2}{|c|}{$\begin{array}{l}\text { Total number of } \\
\text { particle }\end{array}$} \\
\hline & $\begin{array}{c}\text { MMA } \\
(\mathrm{ml})\end{array}$ & $\begin{array}{c}\mathrm{ST} \\
(\mathrm{m} l)\end{array}$ & $\begin{array}{l}\text { MMA } \\
\text { (min) }\end{array}$ & $\begin{array}{c}\text { ST } \\
(\mathrm{min})\end{array}$ & $\begin{array}{c}\text { Core } \\
\text { particle } \\
\text { (A) }\end{array}$ & $\begin{array}{l}\text { Composite } \\
\text { particle } \\
\text { (A) }\end{array}$ & $\begin{array}{c}\text { Core } \\
\left(\times 10^{-16}\right)\end{array}$ & $\begin{array}{c}\text { Composite } \\
\left(\times 10^{-16}\right)\end{array}$ \\
\hline 50 & 150 & 150 & 30 & 100 & $1345 \pm 34$ & $7632 \pm 1050$ & 8.8 & - \\
\hline 60 & 150 & 150 & 30 & 60 & $1470 \pm 48$ & $5891 \pm 992$ & 6.7 & - \\
\hline 70 & 150 & 150 & 20 & 40 & $1501 \pm 47$ & $1718 \pm 93$ & 6.3 & 8.1 \\
\hline 80 & 150 & 150 & 40 & 96 & $1541 \pm 54$ & $2006 \pm 54$ & 5.8 & 5.4 \\
\hline
\end{tabular}

Polymerization conditions: dispersion medium, water $1600 \mathrm{ml}$; initiator, $\mathrm{K}_{2} \mathrm{~S}_{2} \mathrm{O}_{8}-\mathrm{Na}_{2} \mathrm{~S}_{2} \mathrm{O}_{8}$ redox system $5.0 \times 10^{-3} \mathrm{~mol} / l$; promoter, $\mathrm{CuSO}_{4} 2.5 \times 10^{-5} \mathrm{~mol} / l$; atmosphere, nitrogen; rate of stirring, $250 \pm 10 \mathrm{rpm}$ (lune type paddle, $9 \mathrm{~cm}$ ); $\mathrm{pH}, 2.5 \sim 3.5$.

の場合はサラミソーセージ型の粒子になることを電子顕 微鏡で観察しているのも同様の現象で, 粒子径が小さい 場合はモノマーは粒子表面に吸着され重合がその場所で 進むが，粒子径が大きい場合はモノマーは粒子内に吸収 され粒子全体が膨潤した状態で重合が進むものと考えら れる.

メタクリル酸メチルの水媒体不均一重合の場合には, 生成ポリマー粒子の粒子径が $1000 \mathrm{~A}$ ぐらいならば, ス チレンモノマーの2 段階重合によってポリスチレンを外 殻層とした 2 層構造の複合ポリマーラテックスが生成す ると考えられるので，中心層となるポリメタクリル酸メ チルラテックスの粒子数をできるだけ增加させるため, 過硫酸カリウムーチ才硫酸ナトリウムのレドックス開始 剤に重合促進剤として2 価の銅イオンを添加して重合を 行った. 得られた実験結果を Table 1 に示す.

行った重合条件では, レドックス開始郕が低濃度の $1.0 \times 10^{-8} \mathrm{~mol} / l$ では, 促進剂の銅イオンが高濃度の場 合は, 生成ポリマーラテックスがモノマーに溶け込んだ 状態になって, 複合ポリマーラテックスは生成できなか ったが銅(II) イオン濃度が適当な場合は, 安定な複合ポ リマーラテックスが生成した。 しかし，この場合は第 1 段階目のメタクリル酸メチルの重合が完了しないうち に, 重合開始剤が消費されてしまうため, 重合開始後 10２0 分後に過硫酸塩を追添加して重合を完結させる 必要があったが，最初から同量の過硫酸塩を加えた場合 に比較して，より粒子径の小さい，したがって粒子数の 多い安定なポリマーラテックスが生成している.

過硫酸カリウムーチオ硫酸ナトリウムの濃度が, 5.0 $\times 10^{-8} \mathrm{~mol} / l$ と $10.0 \times 10^{-3} \mathrm{~mol} / l$ の場合は, 銅(II) イ オンの存在下で, 重合速度も速く, 分散性の良い安定な ポリマーラテックスが生成したが，銅イオン濃度が同じ なら, 重合開始剤濃度は高いほど生成ポリマーラテック スの粒子数は城少する傾向が認められた。
重合促進剤の銅(II) イオン濃度は, 生成ポリマーラテ ックスの粒子径にかなり影響し，粒子数の增加に著しい 効果が認められた。しかし粒子数が增加しても行った重 合条件では，重合速度はほとんど変わらず，第 2 段階目 のスチレンの重合では, むしろ減少しているのが特改で あった。これは生成ポリマーの粒子径が比較的大きいた め, そのポリマー粒子に対するモノマーが吸着量が著し く增すこと淿による粒子表面でのゲル効果が, より早い 時期に生じて, 重合が急速に進むためと考えられる. 事 実別報の例 ${ }^{7)}$ でみられるように, 生成ポリマーの粒子径 の小さい場合は, 水媒体不均一重合においても, 乳化重 合と同様に重合速度は粒子数に比例して増加している.

\section{1 .2 重合温度}

次に, メタクリル酸メチルとスチレンの組成比が $1: 1$ の場合について，2 層構造の複合ポリマーラテックスの 生成に対する重合温度の影響について検討した結果を Table 2 に示す.

重合温度が $70^{\circ} \mathrm{C}$ 以上の場合は, 分散性が良く粒度分 布が均一で放置安定性の良い複合ポリマーラテックスが 生成したが，重合温度が $60^{\circ} \mathrm{C}$ 以下の場合は，第 2 段階 目のスチレンの重合において, 重合采内に多量の直径が $1 \mathrm{~mm}$ 以上のビーズ状の粒子塊やスポンジ状の塊状物が 生成し,ポリマーラテックスの粒度分布も著しく広くな って複合ポリマーラテックスの生成条件としては不適当 であった.

電子顕徽鏡写真から求めた第 1 段階目重合生成ポリマ 一ラテックスの平均粒子径は, 重合温度の低い場合の方 が小さくなる傾向が認められたが, 放置安定性を調へてて みると, 明らかに重合温度の低い場合の方が, ポリマー ラテックス粒子の沈降速度が速いことが観察されるの で, 重合温度の低い場合に生成した第 1 段階目の重合に よるポリメタクリル酸メチルラテックス粒子は, 重合の 終了時には $2 \sim 3$ 個の粒子が凝集した 2 次粒子をかなり 


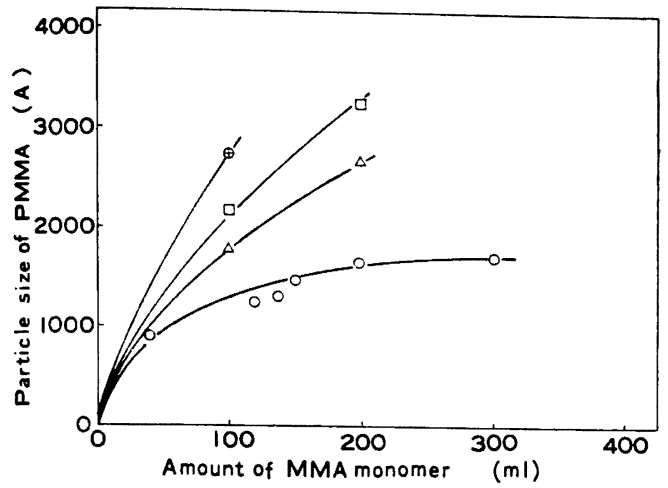

Fig. 1. Relation between the amount of monomer and the particle size of the core polymer formed with $\mathrm{K}_{2} \mathrm{~S}_{2} \mathrm{O}_{8}-$ $\mathrm{Na}_{2} \mathrm{~S}_{2} \mathrm{O}_{3}$ initiator and $\mathrm{CuSO}_{4}$ of various concentration: $\oplus$, nil; $\square, 2.5 \times 10^{-6} \mathrm{~mol} /$ $l ; \triangle, 2.5 \times 10^{-6} \mathrm{~mol} / l ; \bigcirc, 2.5 \times 10^{-4} \mathrm{~mol} / l$.

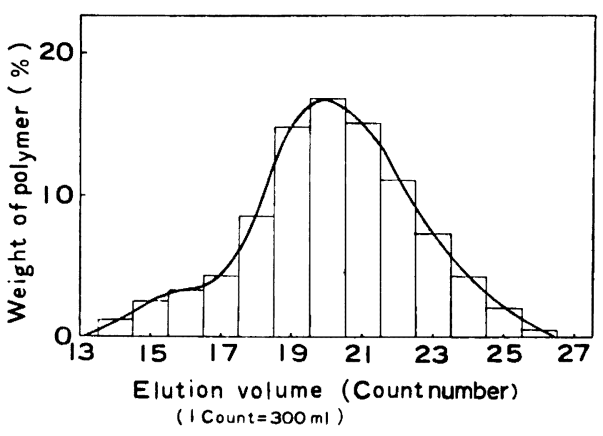

Fig. 2. Normalized molecular weight distribution curve of PMMA-PST polymer composite measured by gel permeation chromatography.

Table 3. The amounts of monomers and particle diameters of the polymer composites

\begin{tabular}{|c|c|c|c|c|c|c|c|c|}
\hline \multicolumn{2}{|c|}{$\begin{array}{l}\text { Amount of } \\
\text { monomer }\end{array}$} & \multirow{2}{*}{$\begin{array}{c}\text { Monomer } \\
\text { ratio }\end{array}$} & \multicolumn{2}{|c|}{$\begin{array}{c}\text { Time of } \\
\text { polymerization }\end{array}$} & \multicolumn{2}{|c|}{ Particle diameter } & \multicolumn{2}{|c|}{$\begin{array}{c}\text { Total number of } \\
\text { particles }\end{array}$} \\
\hline$\underset{(\mathrm{ml})}{\mathrm{MMA}}$ & $\begin{array}{l}\mathrm{ST} \\
(\mathrm{m} l)\end{array}$ & & MMA & ST & $\begin{array}{c}\text { Core } \\
\text { (A) }\end{array}$ & $\underset{\text { (A) }}{\text { Composite }}$ & $\begin{array}{c}\text { Core } \\
\left(10^{-16}\right)\end{array}$ & $\begin{array}{c}\text { Composite } \\
\left(10^{-16}\right)\end{array}$ \\
\hline 40 & 40 & $1: 1$ & 10 & 20 & $911 \pm 29$ & $1245 \pm 84$ & 7.5 & 5.7 \\
\hline 40 & 120 & $1: 3$ & 15 & 50 & $927 \pm 57$ & $1453 \pm 68$ & 7.2 & 7.0 \\
\hline 40 & 200 & $1: 5$ & 15 & 80 & $889 \pm 72$ & $1650 \pm 65$ & 8.1 & 7.3 \\
\hline 40 & 280 & $1: 7$ & 10 & 110 & $886 \pm 48$ & $1745 \pm 62$ & 8.2 & 7.9 \\
\hline 40 & 360 & $1: 9$ & 10 & 170 & $905 \pm 43$ & $2101 \pm 34$ & 7.7 & 6.1 \\
\hline 120 & 60 & $2: 1$ & 15 & 20 & $1303 \pm 37$ & $1428 \pm 41$ & 7.7 & 8.2 \\
\hline 120 & 280 & $3: 7$ & 15 & 80 & $1268 \pm 36$ & $1991 \pm 70$ & 8.4 & 7.0 \\
\hline 135 & 15 & $9: 1$ & 15 & 15 & $1420 \pm 37$ & $1558 \pm 27$ & 6.7 & 5.6 \\
\hline 140 & 60 & $7: 3$ & 20 & 20 & $1333 \pm 25$ & $1462 \pm 56$ & 9.0 & 8.4 \\
\hline 150 & 150 & $1: 1$ & 20 & 40 & $1501 \pm 47$ & $1718 \pm 93$ & 6.3 & 8.1 \\
\hline 200 & 100 & $2: 1$ & 25 & 110 & $1640 \pm 99$ & $1897 \pm 78$ & 6.4 & 6.2 \\
\hline 300 & 100 & $3: 1$ & 30 & 70 & $1700 \pm 25$ & $2111 \pm 47$ & 8.7 & 6.1 \\
\hline 800 & 320 & $5: 2$ & 65 & 30 & $2307 \pm 66$ & $2780 \pm 81$ & 5.8 & 4.6 \\
\hline
\end{tabular}

Polymerization conditions: dispersion medium, water $1600 \mathrm{ml}$; initiator, $\mathrm{K}_{2} \mathrm{~S}_{2} \mathrm{O}_{8}-\mathrm{Na}_{2} \mathrm{~S}_{2} \mathrm{O}_{3}$ redox system $5.0 \times 10^{-3} \mathrm{~mol} / l$; promoter, $\mathrm{CuSO}_{4} 2.5 \times 10^{-5} \mathrm{~mol} / l$; rate of stirring, $250 \pm 10 \mathrm{rpm}$ (lune type paddle, $9 \mathrm{~cm}$ ); atmosphere, nitrogen; temperature, $70 \pm 0.5^{\circ} \mathrm{C} ; \mathrm{pH}, 2.5 \sim 3.5$.

形成していて，そのため，第 2 段階目の重合モノマーで あるスチレン:こ対して著しく親和性が生じてきで)， ポ リマー粒子がェノマーに溶解抽出された大量の塊状物を 生成するものと考えられる.

\section{1 .3 モノマーの仕込み是}

2 㬝構造の複合ポリマーラテックスの生成条件の一つ として, 前述のように, 第 1 段階目の重合で生成したポ
リマー粒子は分散灾定性が良く，粒子径も適当な大きさ でないと，後から添加されるスチレンモノマーに溶解抽 出されて塊状物を形成するようになるので, 第 1 段階目 の重合のモノマーの俅込み量が問題となってくる.

重合開始剂濃度を一定にして，銅(II) イオン濃度を変 化させた場合の $70^{\circ} \mathrm{C} に$ 㕲ける第 1 段階目の重合である メタクリル酸メチルの仕込み冝と生成ポリマーラテック 
スの粒子径との関係を Fig. 1 に示す.

生成ポリマーラテックスの粒子径は，モノマーの仕込 み量の増加とともに，ほぼ立方根の割合で增加していて 銅イオン濃度が高い $2.5 \times 10^{-4} \mathrm{~mol} / l$ の場合は, 粒子数 が多いので, かなり多量のモノマーを用いても粒子径が 2000A 位の安定なポリマーラテックスが得られるのでポ リスチレンとポリメタクリル酸メチルの組成比が任意の 割合の高濃度の複合ポリマーラテックスが生成し得た。

これに対して，銅イオン濃度がより低くい場合は，生 成ポリマー粒子数がより少なくなるので, 第 1 段階目の 重合によって生成したポリメタクリル酸メチルの粒子径 はかなり大きくなるため, 第 2 段階目の重合のスチレン モノマーの仕込み量は，行った重合条件では 100 200 $\mathrm{ml}$ ぐらいが限界量であった。これは前報もで報告した ように, 重合系内に遊離のモノマーが存在する場合に, 生成ポリマーの粒子径が 3000 4000A ぐらいになると 別に新しい重合の活性核種を生成して，重合が進むため 重合の経過とともに粒度分布に二つの山を生じたり，粒 子が相互に合一を起こすほか，生成ポリマー粒子がモ， マーに溶解抽出されるため安定な複合ポリマーラテック スが得られなくなるためである8).

\section{2 複合ポリマーラテックスの分子量分別}

2 層棈造のポリマーラテックスを生成させる方法とし て，水媒体中で第 1 段階目の重合で生成したポリメタク リル酸メチルの粒子上で，第 2 段階目のスチレンの重合 を行うことから，部分的にポリメタクリル酸メチルに対 するスチレンのグラフト重合が起こる可能性がある.グ ラフト重合の確認の方法としては, 薄層クロマトグラフ による分離 ${ }^{22)}$ や濁度滴定などの方法 ${ }^{23)}$ があるが，ここで は PREP 型 GPC で，ポリメタクリル酸メチルとポリ スチレンが $1: 1$ の割合の複合ポリマーの分子量分別を 行ってみた. 得られた結果を Fig. 2 に示す. 分別曲線 をみると低カウント側，すなわち，高分子量側に小さな 一つの分布の山が恝められた。ポリメタクリル酸メチル やポリスチレンの GPCによる分別曲線は, 通常ガウス 型の対称的な分布曲線を示すことを考えると，この高分 子量側に認められる小さな分布は，ポリメタクリル酸メ チルにスチレンがグラフト重合したために高分子量のポ リマーが生成したものとも考えられ，ほぼ 10\%ぐらい のグラフト重合部分を含むものと考えられる.

\section{3 ポリメタクリル酸メチルーポリスチレンから成} る2 層構造複合ポリマーラテックスの生成

次に, 安定なポリメタクリル酸メチルラテックスの得 られた重合条件で, 種々のモノマー量の組成比から成る 複合ポリマーラテックスを生成した実験結果を Table 3 に示す. 実験誤差を考虑に入れると, 行った重合条件で は, いずれの場合も第 1 段階目の重合で生成したポリメ タクリル酸メチルの全粒子数と第 2 段階目の重合でスチ

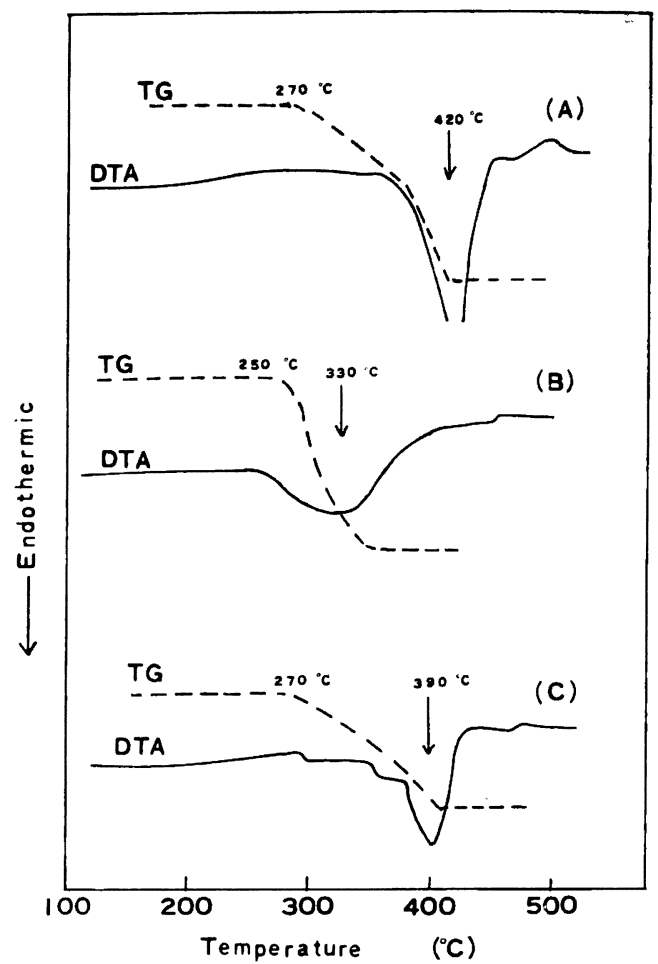

Fig. 3. DTA of (A), polystyrene, (B), poly(methyl methacrylate), and (C), composite of polymers (A) and (B) in 1:1 ratio.

レンが複合化された 2 層構造の複合ポリマーラテックス の全粒子数はほぼ同じであった。このように生成ポリ、 一の粒子数が一定であることと, 生成ポリマーラテック スの粒度分布が，かなり狭いこと，および第 2 段階目の スチレンの重合は，すべて第 1 段目の重合で生成したポ リメタクリル酸メチルの粒子表面層で重合が進行してい るとみなすならば，ポリメタクリル酸メチルを中心にし て，ポリスチレンが層状に重なっている複合ポリマーが 生成しているとみなせる.

複合ポリマーラテックスの生成速度は, 第 1 段階目の 重合で生成したポリメタクリル酸メチルの粒子数が一定 なので粒子径に依存していると考えられる.

\section{4 圧縮成形ポリマーの性犋}

Table 1〜3で示した種々のポリマー組成の異なる複 合ポリマーラテックスを乾燥後, 圧縮成形を行って成形 樹脂の定性的観察を行った. 前述のようにして得られた ポリメタクリル酸メチルとポリスチレンから成る複合ポ リマーラテックス粒子を压縮成形した場合，粒子径が $2000 \mathrm{~A}$ 以下の場合の複合ポリマー粒子から得られた成 形樹脂片は，透過光線に対しては黄色であり，反射光に 
対しては青色から青白色に見える透明ないし半透明の iridescent color（見る角度によって色の変わる）の樹 脂であった。また，粒子径が $2000 \mathrm{~A}$ 以上の大きい場合 の複合ポリマー粒子から得られた成形樹脂片は, 乳白色 から白色の不透明なものとなり，この場合はポリマー 組成比が $1: 9$ の場合でも白色の不透明な樹脂であっ た.

成形樹脂の機械的強度は, 定性的には成分ポリマー単 独の成形樹脂のそれと，それほど変わっておらず，組成 比が $1: 1$ の場合に, ややもろい程度で相溶性の悪いポ リマーどらしのブレンドの組合せ例としては，予想以上 の強度を保持しているよらである.このことは, 前項で 述ベたよに, 両成分のポリマー間に部分的なグラフト 重合部分が存在して, このグラフト重合部分が両成分ポ リマー間の界面の親和性に関与していることと，ポリマ 一ぞうしの混合がミク口的不均一混合が十分に行われて いるために, 相分離に伴ら強度の低下が少ないのである 5 .

次にポリメタクリル酸メチルとポリスチレン単独の場 合と組成比が $1: 1$ の 2 層構造複合ポリマーの示差熱曲 線と加熱减量曲線の比較を行った。その結果は Fig. 3 に 示すよらに, 複合ポリマーの解重合に上る分子の切断と 考えられる吸熱ピークは, ポリスチレンの吸熱ピークと ポリメタクリル酸メチルの吸熱ピークのほぼ中間にあっ て1本の鋭いピークを示し，かなり混合状態の良いこと を示している.

\section{4 総 括}

一つのポリマー粒子中に，2成分以上のポリマーを含 有させた複合ポリマー粒子を得る方法と, 二つのガラス 相から成る非相溶性ポリマーのミク口的不均一混合のブ レンドポリマーについて検討を行った．結果を要約する と，1）過硫酸塩とチ才硫酸塩などから成るレドックス 重合開始剤に，微量の銅(II) イオンを添加することによ って,メタクリル酸メチルとスチレンの 2 段階水媒体不 均一重合によって分散性の良い安定な複合ポリマーラテ ックスが得られた。2) 生成ポリマーの粒子径は，銅イ オン濃度とモノマーの仕込及量に依存していて, 特に第 1段階目のメタクリル酸メチルの粒子径が $3000 \mathrm{~A}$ 以上 になると複合ポリマーラテックスは得られなかった，3） 複合ポリマーラテックスの生成に対する重合温度の影響 は大きく, 重合温度が $70^{\circ} \mathrm{C}$ 以上の場合は安定なポリマ ーラテックスが得られたが, 温度が $60^{\circ} \mathrm{C}$ 以下の場合 は, 部分的な凝集体を作り, 安定な複合ポリマーラテッ クスが得られず多量の塊状物を生成した，4）圧縮成形 に上る成形ポリマーは, 生成複合ポリマーラテックスの 粒子径によって異なる透明から不透明の見る角度によっ て変わる色を持った特異な樹脂であり, 非相溶性のポリ
マーの混合体としては子想以上の強度を保持しているこ とが認められた。

付 記 本報上ほ济同内容のものを第 21 回高分子剖 論会 (1972 年, 大阪) で発表した。

\section{文献}

1) A. Dobry, F. B. Kawenoki: J. Polym. Sci., 2, 90 (1947).

2) 特公 昭 39-220.

3) B. Pat. 627,265 (1946), B. Pat. 941,064 (1963), B. Pat. 1,009, 486 (1965), U.S. Pat. 3, 282, 876 (1966), U.S. Pat. 3, 309, 330 (1967), U.S. Pat. 3,236,798 (1966), U.S. Pat. 3, 305, 505 (1967), U.S. Pat. 3, 296, 176 (1967), U. S. Pat. 3, 301, 806 (1967).

4) P. F. Keusch, J. Prince, D. J. Williams: J. Macromol Sci. Chem., A7(3), 623 (1973).

5) J. B. Yannas, I. E. Isgur: J. Polym. Sci., A2, 4719 (1964).

6) 松本恒隆, 大久保政芳, 今井 正：高分子論 集, 31, 576 (1974).

7）山崎信助, 浜島求女, 石上 裕：高分子論集, 33, 549 (1976).

8) 山崎信助, 服部 滋, 浜島求女：高分子化学, 27, 600 (1970).

9) 山崎信助, 福田 稳, 浜島求女: 高分子化学, 25, 203 (1968).

10）大塚保治：有機合成協会誌，25，879 (1967).

11) L. H. SperLing, T. Chiu, C. P. Hartman, D. A. Thomas: Intern. J. Polym. Mater. 1, 331 (1972).

12）松本恒隆，大久保政芳：日接着協誌，10，105 (1974).

13) J. Stabenow, F. Haaf: Angew. Makromol. Chem., 20/30, 1 (1973).

14) 山崎信助: 高分子論集, 33, 663 (1976).

15) J. L. Gardon: J. Polym. Sci., A-1, 6, 2859 (1968).

16) E. Vanzo, R. H. Marchessault, V. Stannett: J. Colloid Sci., 20, 62 (1965).

17) P. J. Flory: "Principles of Polymer Chemistry" p. 211 (1953) Cornell University Press Ithraca, New York.

18) M. R. Grancio, D. J. Williams: J. Polym. Sci., A-1 8, 2617, 2733 (1970).

19) P. Keusch, D. J. Williams: J. Polym. Sci., Polym. Chem. Ed., 11, 143, 301 (1973).

20) P. Keusch, R. A. Graff, D. J. Williams: Macromolecules, 7, 304 (1974).

21) J.W. Vanderhoff: Water-Born Polymers and High Solid Coating Symposium, New Orleans, February (1976). 
22) B. G. Belenkii, E. S. Gankina: J. Chlomatography, 53, 3 (1970).
23) P. Molyneux: Makromol. Chem., 43, 31 (1961).

Preparation of Two-Layer Structure Composite Polymer Latex Particles Consisting of Poly (methyl methacrylate) and of Polystyrene by Two-Stage Heterogeneous Polymerization in Aqueous Medium

Shinsuke YamaZaki*1, Shigeru Hattori*1, and Motome Hamashima*1

${ }^{* 1}$ National Chemical Laboratory for Industry (1-5, Honmachi 1-chome, Shibuya-ku, Tokyo 151)

The production technique for composite polymer latex with a two-layer structure was investigated. (1) The two-layer structure composite polymer latex was produced in water medium by twostage heterogeneous polymerization method in which the first methyl methacrylate polymerization and the second styrene polymerization were carried out with stirring at $70^{\circ} \mathrm{C}$ by using $\mathrm{K}_{2} \mathrm{~S}_{2} \mathrm{O}_{8}-$ $\mathrm{Na}_{2} \mathrm{~S}_{2} \mathrm{O}_{3}$ redox system as initiator and cupric ion as accelerator. (2) The polymer particle, thus obtained, essentially consisted of the inner core of poly (methyl methacrylate) and the outer shell of polystyrene. (3) The formation of this core-shell polymer particles required to satisfy the condition that a stable and monodispersed poly (methyl methacrylate) latex with its particle size of below 2000A was formed first. (4) Though the two-layer structure polymer latex was composed of micro-heterogeneous mixture of two kinds of immisible polymers, the film molded from the composite latex showed a good mechanical strength. (5) The film molded from the particle diameter of below 2000A showed a transparent iridescent color while the film molded from the particle diameter above $3000 \mathrm{~A}$ showed an intense opaque iridescent color.

KEY WORD Poly(methyl methacrylate) / Polystyrene / Two-layer polymer / Micro-heterogeneous mixture / Iridescent color /

(Received March 3, 1976: Accepted July 8, 1976)

[Kobunshi Ronbunshu, 33(11), 655-662 (1976)] 